\title{
Peningkatan Keterampilan Bahasa Inggris Pemuda Karang Taruna Desa Mambalan Melalui Media Audio Visual
}

\author{
Zainudin Abdussamad ${ }^{1}$, Sutarman ${ }^{2}$, Wahyu Kamil Syarifaturrahman ${ }^{3}$ \\ samadzain12@gmail.com', sutarman@universitasbumigora.ac.id ${ }^{2}$, \\ wahyu.kamil@universitasbumigora.ac.id ${ }^{3}$
}

1,2,3 Universitas Bumigora

\begin{tabular}{l}
\hline Article History: \\
Received: 05-01-2021 \\
Accepted: 28-01-2021
\end{tabular}

Keywords: Audio visual, skill, Mambalan

\begin{abstract}
Mambalan is a village located in the Gunung Sari, West Lombok, where most of the population lived as farmer laborers and stone breaking. With a small income, of course it has an impact on the ability of parents to send their children to a higher level of education. Based on conditions above, the writer and team are interested in conducting community service by providing English language training using audio-visual media for the youth organization. This training used an audio-visual media method with the aim of making the training activities more interesting and easier for the training participants. This English training activity has positive impact for the youth organization of Mambalan village. These positive impacts seen through the result of the training process. Within a few months of following the training process by using audio-visual media, the learning outcomes of the training participants increased. Before participating in the training, the training participants considered English was a difficult language to learn, but after participating in the training by using audio-visual media the trainees began to experience convenience and the trainees thought that learning English using audio-visual media was fun.
\end{abstract}

\section{Pendahuluan}

Pengabdian kepada masyarakat merupakan salah satu dharma atau tugas pokok dari suatu perguruan tinggi, disamping dharma pengajaran, dharma penelitian serta dharma pengabdian pada masyarakat. Khusus untuk dharma pengabdian pada masyarakat, dosen di tuntut untuk melakukan kegiatan pengabdian kepada masyarakat dengan terjun secara langsung untuk menerapkan ilmu yang dimiliki kepada masyarakat khususnya pada daerah atau lokasi yang menjadi sasaran kegiatan pengabdian seperti yayasan, instansi atau desadesa terpencil yang masih kekurangan sumberdaya yang memadai. Salah satu desa yang saat ini bisa dijadikan sebagai lokasi pengabdian adalah desa Mambalan yang berada di wilayah Kabupaten Lombok Barat Kecamatan Gunungsari.

Berdasarkan data dari situs resmi Desa Mambalan, (2020) tercatat desa Mambalan memiliki penduduk sekitar $750 \mathrm{KK}$ dengan 2150 jiwa yang tersebar di 4 dusun. Desa Mambalan merupakan desa tertua yang telah melahirkan 7 desa lainnya yang ada di 
kecamatan Gunungsari. Adapun dusun yang menjadi wilayah Desa Mambalan ada 4 dusun yaitu:

1. Dusun Mambalan,

2. Dusun Buwuh,

3. Dusun Batu Riti,

4. Dusun Lilir Barat (setengah wilayah Dusun Lilir Barat menjadi wilayah Desa Jeringo dengan nama Dusun Jeringo Timur).

Desa Mambalan patut berbangga dengan keadaan dan tipologi alamnya yang menjanjikan. Hamparan sawah di kiri kanan jalan masih nampak menghijau dan subur karena Desa Mambalan merupakan daerah pertanian dan sebagian besar penduduknya hidup dari bercocok tanam. Bagi masyarakat luar, Desa Mambalan sangat terkenal tipologi alamnya yang menjanjikan. Di samping itu, Desa Mambalan juga dikelilingi oleh objek wisata alam yang sangat indah berupa pegunungan seperti bukit korea, air terjun guripak, bukit tiga rasa dll yang bisa mengundang tamu domestik maupun luar untuk datang berkunjung ke Desa Mambalan. Dengan kondisi alam yang dimiliki oleh Desa Mambalan tersebut di atas, sudah tentu Desa Mambalan harus siap menyambut kedatangan tamu khususnya tamu mancanegara. Untuk itu dibutuhkan keterampilan bahasa Inggris bagi pemuda-pemuda setempat khususnya bagi pemuda yang tergabung dalam pemuda karang taruna Desa Mambalan Kecamatan Gunung Sari.

Berdasarkan hasil pengamatan khususnya pada bidang pendidikan, Desa Mambalan sudah memiliki awig-awig terkait dengan pendidikan yang merupakan salah satu turunan dari aturan-aturan adat yang ada di Desa Mambalan yang selanjutnya di jadikan sebagai pedoman dalam menjalankan aktivitas bermasyarakat. Awig-awig bidang pendidikan mengatur tentang kewajiban memenuhi hak anak untuk mendapatkan pendidikan yang layak. Terkait dengan awig-awig bidang pendidikan, untuk memberikan hak anak mendapatkan pendidikan yang layak, di Desa Mambalan masih ditemukan siswa kurang mampu dan siswa putus sekolah. Hal ini disebabkan karena kondisi ekonomi keluarga sehingga siswa bersekolah dengan kondisi apa adanya. Siswa putus sekolah dan kurang mampu ini tergabung dalam organisasi karang taruna yang ada di Desa Mambalan.

Mengingat akan kondisi di atas dan keinginan untuk membantu pemerintah untuk mencerdaskan kehidupan bangsa melalui pendidikan (Mada, 1945), maka penulis memandang perlu untuk memberikan kegiatan yang positif bagi pemuda karang taruna Desa Mambalan dalam bentuk pelatihan bahasa Inggris yang bisa mengembangkan kemampuan dan keterampilan pemuda karang taruna di desa tersebut dengan harapan, 
nantinya setelah mereka mengikuti pelatihan bahasa Inggris mereka akan memiliki keterampilan bahasa Inggris yang bisa digunakan untuk mencari pekerjaan.

\section{Metode}

Dalam pelaksanaan pelatihan bahasa Inggris bagi pemuda karang taruna Desa Mambalan ini sudah tentu dibutuhkan metode yang sifatnya bisa mempermudah dan membantu kegiatan pelatihan ini. Pelatihan ini menggunakan metode pelatihan dengan menggunakan media audio visual dengan tujuan agar kegiatan pelatihan lebih menarik dan mudah di pahami Pasha, (2019) serta diperaktikkan oleh peserta pelatihan. Penerapan metode ini menggunakan strategi sebagai berikut :

1. Teori

Dalam pelatihan bahasa dibutuhkan dasar berupa teori. Teori ini terkait dengan gambaran umum tentang bahasa Ingris dan materi yang akan di bahas dalam praktik. Selain itu dalam teori dibahasa pula kiat-kiat sukses dalam belajar bahasa Inggris. Adapun pemberian teori ini berguna untuk menunjang kegiatan praktik.

2. Praktik

Untuk menunjang pelatihan bahasa Inggris dibutuhkan kegiatan pengalaman secara langsung yaitu berupa praktik. Praktik ini berupa pemutaran video dalam bahasa inggris yang berisi penggunaan bahasa Inggris dalam kegiatan sehari-hari. Setelah pemutaran materi berbasis audio visual, peserta diminta untuk mempraktikkan apa yang sudah didapat dari pelatihan dalam bentuk praktik berbicara.

3. Evaluasi

Evaluasi bertujuan untuk melihat seberapa efektif kegiatan yang telah dilakukan dan mengetahui kekurangan sehingga akan menjadi bahan masukan dan perbaikan pada kegiatan pengabdian masyarakat berikutnya.

\section{Pembahasan}

Langkah awal yang kami lakukan dalam kegiatan pengabdian masyarakat di Desa Mambalan adalah dengan mengadakan survey dan pendekatan kepada penduduk setempat. Pendekatan dilakukan untuk mengetahui kondisi riil dari pemuda di desa tersebut. Kegiatan pendekatan ini dilakukan kurang lebih selama satu bulan. Adapun kegiatan pendekatan pertama yang dilakukan adalah mendatangi kepala desa dan staf yang bertanggung jawab atas kegiatan yang terkait denga kepemudaan dengan tujuan selain untuk menyampaikan maksud dan tujuan dari kegiatan pengabdian juga untuk mendapatkan informasi terkait dengan kondisi pemuda setempat . Berdasarkan pendekatan dan informasi 
dari kepala desa, terdapat sekitar 25 pemuda tingkat SMP dan sederajat yang kurang mampu di desa tersebut. Sebagian besar dari 25 pemuda tersebut merupakan pemuda yang orang tuanya bekerja sebagai buruh tani dan sebagai pemecah batu. Para pemuda ini terhimpun dalam pemuda karang taruna Desa Mambalan.

Untuk proses kegiatan pelatihan diadakan di kantor Desa Mambalan dan salah satu rumah warga yang bersedia rumahnya untuk digunakan sebagi tempat dilakukannya kegiatan pelatihan. Adapun materi yang diberikan kepada peserta pelatihan adalah berupa materi dasar bahasa Inggris dan praktik langsung dalam bentuk percakapan. Materi disajikan dengan menggunakan media audio visual dengan tujuan agar pembelajaran berlangsung dengan lebih menarik sehingga mereka termotivasi untuk tetap mengikuti pelatihan. Waktu pelatihan diadakan satu kali dalam seminggu dengan waktu belajar sekitar 2 jam.

Dalam beberapa bulan menjalani proses pelatihan dengan menggunakan media audio visual terlihat peningkatan hasil belajar peserta pelatihan. Sebelum mengikuti pelatihan peserta pelatihan menganggap bahasa Inggris merupakan bahasa yang sulit untuk dipelajari namun setelah mengikuti pelatihan dengan menggunakan media audio visual peserta pelatihan mulai mengalami kemudahan dan peserta pelatihan menganggap bahwa belajar bahasa inggris dengan menggunakan media audio visual terasa menyenangkan. Terlihat juga beberapa pemuda karang taruna sudah mulai menggunakan percakapan ringan ketika berinteraksi dengan sesame peserta pelatihan.

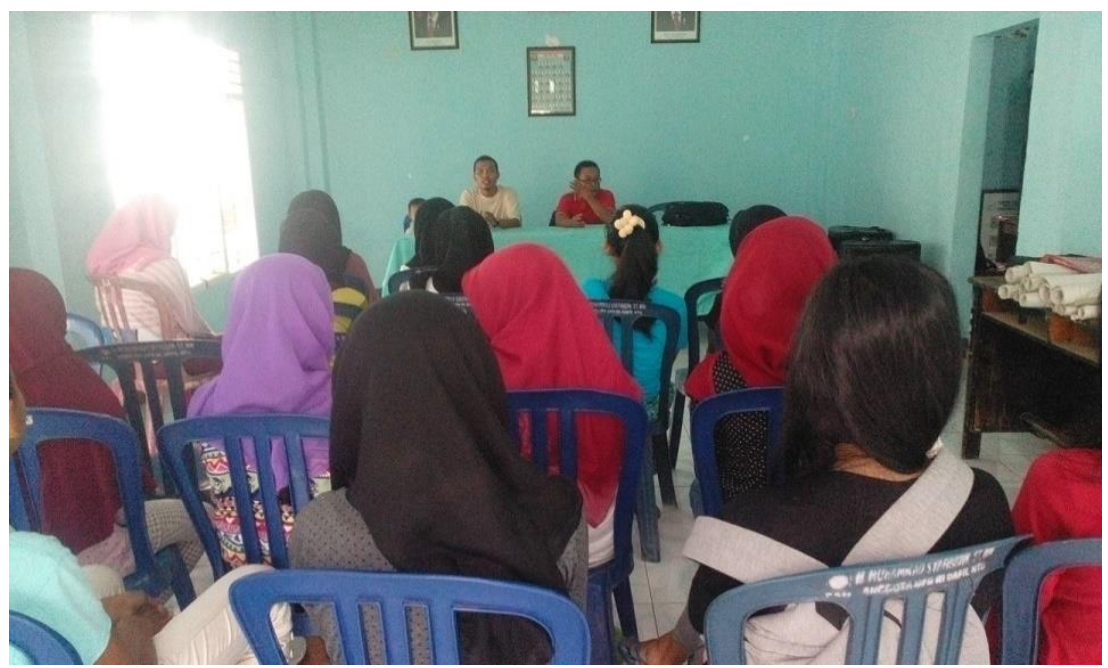

Gambar 1. Foto dokumentasi pelaksanaan pengabdian 1 


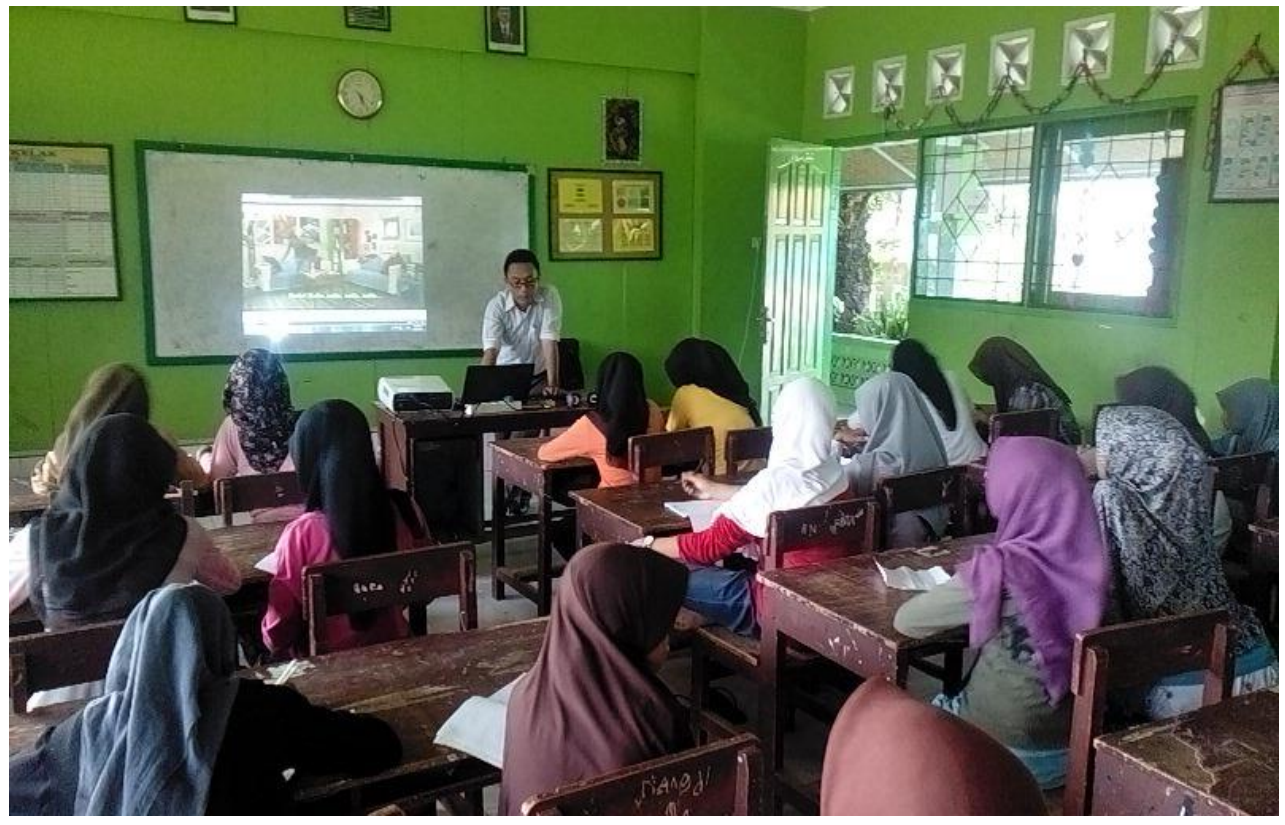

Gambar 2. Foto dokumentasi saat penjelasan materi

\section{Kesimpulan}

Pembelajaran dengan menggunakan Media audio visual dapat meningkatkan motivasi dan meningkatkan keterampilan bahasa Inggris pemuda karang taruna desa Mambalan kecamatan gunungsari Lombok Barat sesuai dengan penelitian yang telah dilakukan (Purnaningsih, 2017), (Ningsih et al., 2014), (Evyanto, 2018). Kegiatan pelatihan bahasa inggris yang diberikan kepada pemuda karang taruna memberikan dampak positif bagi pemuda di desa tersebut. Pemuda yang sudah terlibat dalam kegiatan pelatihan tersebut dapat mengajarkan ilmu yang didapat kepada teman-teman lain di kampung tersebut.

Kegiatan pelatihan bahasa inggris yang dilakukan di Desa Mambalan kecamatan Gunungsari ini merupakan kegiatan positif yang bisa memberikan dampak positif bagi pemuda karang taruna di desa tersebut, ntuk itu maka kegiatan semacam ini agar terus ditingkatkan bukan hanya bagi pemuda di wilayah Desa Mambalan melainkan juga bagi pemuda desa-desa lain yang memerlukan pembinaan dan peningkatan keterampilan.

\section{Ucapan Terimakasih}

Ucapan terima kasih yang tak terhingga diberikan kepada Universitas Bumigora selaku pelindung dalam kegiatan pengabdian ini. kami juga ucapkan terima kasih kepada Ketua LPPM beserta jajarannya yang telah memberikan dukungan dan bantuan dalam kegiatan ini sehingga pengabdian ini bisa berjalan dengan lancar. Tidak lupa pula kami sampaikan apresiasi kepada Kepala Desa Mambalan dan staf-stafnya beserta anggota 
Karang Taruna Desa Mambalan yang dengan senang hati untuk menerima dan meluangkan waktunya dalam mengikuti kegiatan ini. pada akhirnya, kami berharap semoga kegiatan ini memberikan manfaat bagi para peserta peltaihan khususnya dan Desa Mambalan pada umumnya.

\section{Daftar Pustaka}

Evyanto, W. (2018). Efektifitas Media Audio Visualdalam Meningkatkan Keterampilan Berbicara Bahasa Inggris Siswa. Jurnal Basis, 5(1), 65-74. https://doi.org/10.33884/basisupb.v5i1.454

Mada, universitas G. (1945). Undang-undang Dasar RI Tahun 1945. Universitas Gajah Mada. https://luk.staff.ugm.ac.id/atur/UUD1945.pdf

Mambalan, W. D. (2020). Profile desa. Website Resmi Desa Mambalan. https://mambalan.desa.id/gambaran-umum-desa/

Ningsih, M. G. S., Mudjiman, H., \& Haryanto, S. (2014). Penerapan Media Visual dalam Pembelajaran Bahasa Ingris. Jurnal Teknologi Pendidikan Dan Pembelajaran, 2(1), 79-92. https://media.neliti.com/media/publications/141592-ID-penerapan-media-audio-visual-dalampembe.pdf

Pasha, A. C. (2019). 6 Jenis Media Pembelajaran Sederhana, Bisa Bantu Siswa Agar Tidak Bosan. Liputan6.Com. https://www.liputan6.com/citizen6/read/3921556/6-jenis-media-pembelajaransederhana-bisa-bantu-siswa-agar-tidak-bosan

Purnaningsih, P. (2017). Strategi Pemanfaatan Media Audio Visual Untuk Peningkatan. Jurnal Informatika Universitas Pamulang, 2(1), 34-41. https://www.researchgate.net/publication/336117416_Strategi_Pemanfaatan_Media_Audio_Visu al_untuk_Peningkatan_Hasil_Belajar_Bahasa_Inggris/link/5d8f5a0b299bf10cff15989b/download 